\title{
Positive, negative and marker-free strategies for transgenic plant selection
}

\author{
Francisco José Lima Aragão* and Ana Cristina Miranda Brasileiro
}

Laboratório de Transferência de Genes, Embrapa Recursos Genéticos e Biotecnologia

Parque Estação Biológica, Final Av.W5 Norte, 70.770-900, Brasília, DF, Brasil; * Corresponding author: aragao@cenargen.embrapa.br

In this review, the use of the most common selection marker genes on plant transformation and the effects of their respective selective agents are discussed. These genes could be divided in two categories according their mode of action: genes for positive and negative selection. The retention of the marker gene flow through chloroplast transformation is also discussed. Further, strategies to recover marker-free transgenic plants, involving multi-auto-transformation (MAT), cotransformation, site-specific recombination and intragenomic relocation of transgenes through transposable elements are reviewed.

Key Words: Antibiotic resistance, herbicide resistance, marker genes, plant transformation, selection, transgenic plant

Estratégias de seleção positiva, negativa e livre de marcadores para obtenção de plantas transgênicas: Nesta revisão, os genes marcadores de seleção mais comumente utilizados em transformação de plantas serão discutidos, bem como os efeitos de seus respectivos agentes seletivos. Estes genes podem ser divididos em categorias de acordo com o modo de ação: genes para seleção positiva e negativa. A contenção do fluxo gênico através da transformação de cloroplastos também é discutida. Além disso, as estratégias utilizadas para obtenção de plantas sem marcadores são abordadas, envolvendo multi-auto-transformação (MAT), co-transformação, recombinação sítio-específica e realocação intragenômica de transgenes por transposons.

Palavras-chave: Genes marcadores, resistência a antibiótico, resistência a herbicida, planta transgênica, seleção, transformação de plantas.

\section{INTRODUCTION}

The use of a marker gene in a transformation process aims to give a selective advantage to the transformed cells, allowing them to grow faster and better, and to kill the non-transformed cells (Brasileiro and Dusi, 1999). In general, the selective gene is introduced into the plant genome along with the genes of interest. In some cases, the marker gene is the gene of interest that will express an agronomic characteristic, such as herbicide resistance.

The selective gene and the genes of interest may be separated or physically linked in the same DNA vector. The frequency of co-transformation (i.e. cells with both genes integrated into the genome) is about $100 \%$ when the genes are linked and $50 \%$ when they are separated (Aragão et al., 1996). The selective agents are generally used in the initial stages of transformation for an early selection of transgenic cells (Sawahel, 1994). During the following regeneration steps, the influence exerted by the death of nontransformed cells on the transformed cells should be minimal on the selective medium. In most cases, the expression of selection marker genes is under the control of a constitutive promoter such as the cauliflower mosaic virus (CaMV) 35S, nopaline and octopine synthase, actin or ubiquitin gene promoters. In some cases, the marker gene expresses an agronomic characteristic, such as herbicide resistance.

The aim of this review is to list and discuss the most common selection marker genes used in plant transformation and the effects of their respective selective agents. The strategies currently used to further eliminate the selection marker gene are also reviewed. 


\section{Markers genes for positive selection}

Some marker genes for positive selection enable the identification and selection of genetically modified cells without injury or death of the non-transformed cell population (negative selection). In this case, the selection marker genes should give the transformed cell the capacity to metabolize some compounds that are not usually metabolized. This fact will give the transformed cells an advantage over the non-transformed ones. The addition of this new compound in the culture medium, as nutrient source during the regeneration process, allows normal growth and differentiation of transformed cells, while non-transformed cells will not be able to grow and regenerate de novo plants.

The gus gene: The gene gus codes for the $\beta$-glucuronidase enzyme (GUS; EC 3.2.1.31) and was isolated from Escherichia coli. This gene is widely used as a reporter gene in transgenic plants. In this system, the selective agent is a glucuronide derivative of benzyladenine (benzyladenine N3-glucuronide), an inactive form of the plant hormone cytokinin. This glucuronide present in the selection medium can be hydrolyzed by the GUS enzyme produced in the transformed cells, releasing active cytokinin (benzyladenine) in the medium. This cytokinin will be a stimulator for transformed cell regeneration while nontransformed cell development is arrested.

The selective agent (benzyladenine N-3-glucuronide) does not have any effect on the non-transformed cells because the cytokinin is in its inactive form.

There is only one report concerning the successful use of this system in the effective recovery of transgenic plants (Joersbo and Okkels, 1996; Okkels et al., 1997).

The manA gene: The man gene codes for the phosphomannose isomerase enzyme (PMI; EC 5.3.1.8) isolated from Escherichia coli. In the presence of mannose, the PMI converts mannose-6-phosphate into fructose-6phosphate in transformed cells that can be immediately incorporated in the plant metabolic pathway. Thus, mannose can be used as the sole carbohydrate source for the transformed cells. This selection system is immediate and extremely efficient (Joersbo et al., 1998).

Mannose cannot usually be metabolized by nontransformed cells and is converted into mannose-6-phosphate by endogenous hexokinase. Therefore, when man- nose is added to the culture medium, plant growth may be minimized due to mannose-6-phosphate accumulation. The mannose-6-phosphate toxicity in plant cells was shown to be responsible for apoptosis, or programmed cellular death, through induction of an endonuclease, responsible for DNA laddering (Stein and Hansen, 1999). Mannose-6-phosphate accumulation also causes phosphate and ATP starvation that deplete cell of energy for critical functions such as cell division and elongation, giving rise to growth inhibition. Therefore, mannose is a hexose that fills the desirable requirements for a good selection agent: it is (a) soluble in plant culture media; (b) absorbed by plant cells; (c) cheap; (d) easily available and (e) safe.

Although most plant species are sensitive to mannose, some species, especially dicotyledonous, have shown a considerable insensitivity to this sugar, including carrot, tobacco, sweet potato and legumes. Other species are extremely sensitive and have been successfully transformed using mannose as selective agent, such as sugar beet, maize, wheat, oat, barley, tomato, potato, sunflower, oilseed rape and pea (Joersbo et al., 1998; 1999; 2000; Negrotto et al., 2000; Wang et al., 2000).

Some plant transformation protocols that use the positive selection system with PMI were at least 10 times more efficient than the traditional protocols based on the use of kanamycin as selection agent (Wright et al., 2001).

The xylA and DOGR 1 genes: A similar positive selection system has been developed using the xylose isomerase gene ( $x y l \mathrm{~A})$ isolated from Thermoanaerobacterium thermosulfurogenes or from Streptomyces rubiginosus, as selection marker gene (Haldrup et al., 1998a; 1998b). Transgenic plants of potato, tobacco and tomato were successfully selected in xylose-containing media.

Recently, the $D O G^{R} 1$ gene encoding 2deoxyglucose-6-phosphate phosphatase (2-DOG-6-P) was used to develop a positive selection system for tobacco and potato plants (Kunze et al., 2001). DOG 1 gene, which has been isolated from yeast, gives resistance to 2-deoxyglucose (2-DOG) when over-expressed in transgenic plants.

Auxotrophic markers: In plants, auxotrophic mutations that require nutritional supplements are unusual and only a few cases can be easily propagated as homozygous. Consequently, the complementation of auxotrophic mutants by 
transformation with a functional gene is rarely reported (Bowen, 1993). Two examples are well known. First, mutants of Nicotiana plumbaginifolia that are deficient in threonine dehydratase require isoleucine for development. These mutants were complemented by transformation with the ILV1 gene from yeast, which codes for the threonine dehydratase. Transformants were selected in medium without isoleucine and the threonine dehydratase enzyme activity was restored. In another example, mutants of $N$. tabacum and $N$. plumbaginifolia that are deficient in nitrate reductase were complemented by transformation with the $n r$ gene from N. tabacum (Vincentz and Caboche, 1991). Transformants were selected in the presence of nitrate and the mutant phenotype was reverted.

\section{Marker genes for negative selection}

The first category of negative selection markers is the genes that express resistance to herbicides. To be used as suitable selective agents, herbicides should have some characteristics that allow their in vitro use. For example, herbicides that act by blocking photosynthesis are not ideal for use in vitro. However, these herbicides could be used to select transformed green tissue when applied directly to the differentiated organs.

Another category of marker genes express resistance to an antibiotic in the plant. These genes correspond to the first genes successfully used to select transgenic plants.

The bar and pat genes: The bar and pat genes were isolated from Streptomyces hygroscopicus and $S$. viridochromogenes, respectively. These similar genes code for the phosphinothricin-N-acetyltransferase enzyme (PAT; EC 2.3.1.-) (Murakami et al., 1986). The PAT enzyme inactivates herbicides with phosphinothricin (PPT) as active compound, such as Basta ${ }^{\mathrm{TM}}$, Liberty ${ }^{\mathrm{TM}}$ and Herbiace ${ }^{\mathrm{TM}}$. The herbicide is detoxified through the acetylation of the PPT free amino group using acetyl coenzyme A as a cofactor that prevents PPT binding to the glutamine synthetase enzyme (GS).

PPT, which is also well known as ammonium glufosinate, is similar to the GS substrate glutamate and acts as a competitive inhibitor of GS. The GS enzyme catalyzes the conversion of glutamate to glutamine, removing the toxic ammonia from the cell. This enzyme plays an essential role in the nitrogen metabolism and ammonia as- similation regulation. When GS is inhibited, ammonia accumulation and an associated disruption of chloroplast structure that leads to photosynthesis inhibition and to plant cell death occurs (Lindsey, 1992).

The bar gene is found in strains of S. hygroscopicus that produce bialaphos, a tri-peptide antibiotic that consists of PPT and two L-alanine residues (Murakami et al., 1986). The bar gene (PAT) product protects these strains from the action of its own antibiotic, metabolizing PPT into an inactive acetylated-derived compound and preventing autotoxicity (De Block et al., 1987; Mazur and Falco, 1989).

The bar gene is the most widely and successfully used selection marker gene for all of the major cereal species, such as wheat, rice, maize, barley, sorghum, oats and rye (Vasil, 1994; Vain et al., 1995).

The aroA (or epsps) gene: This gene was isolated from Salmonella typhimurium treated with a mutagenic agent and selected for resistance to the herbicide glyphosate. The mutated aroA gene codes for a modified form of the 5-enolpyruvyl-shikimate-3-phosphate synthase enzyme (EPSPS; EC 2.5.1.19) that shows reduced affinity to glyphosate, which is the active compound in the commercial Roundup herbicide (Comai et al., 1983; 1985). A high level of the aroA gene constitutive expression in transgenic plants gives resistance to glyphosate. The overproduction of this enzyme results in high enzymatic activities that enable the plant cell to survive even in the presence of the herbicide (Mazur and Falco, 1989).

The herbicide glyphosate inhibits, by competition, the enzyme EPSPS, which is involved in the enzymatic pathway of aromatic amino acids biosynthesis in bacteria and plants. The inhibition of EPSPS results in shikimate accumulation, inhibition of synthesis of aromatic amino acids and secondary metabolites causing cell death.

Other epsps genes which code for an EPSPS event with reduced affinity to glyphosate have also been isolated from the line CP4 of Agrobacterium sp. and from Petunia hybrida. In plants, endogenous EPSPS is mainly localized in the chloroplast. The bacterial aroA gene lacks a transit peptide sequence to move the protein to the chloroplast. Consequently, it originates a cytoplasmic form of the enzyme. Transgenic plants expressing the aro A gene in the cytoplasm showed increased, but incomplete, tolerance to glyphosate. Higher transformation efficiency has been 
achieved by fusing the aroA gene to a chloroplast transit peptide to move the pro-protein into this organelle (Oxtoby and Hughes, 1990).

The csr 1 (or ahas) gene: These genes code for mutated forms of the acetohydroxy acid synthase enzyme (AHAS; EC 4.1.3.18), also called acetolactate synthase (ALS). Each mutant $\operatorname{crs} 1$ gene contains a single nucleotide change, resulting in a single amino acid substitution in the AHAS protein. The crs 1 genes were isolated from mutants of Arabidopsis thaliana resistant to sulfonylurea and imidazolinone herbicides, such as chlorsulfuron, imazapyr and imazaquin (Haughn et al., 1988; Mourad et al., 1995).

Transgenic plants containing one of these mutated crs 1 genes will produce an altered AHAS enzyme, which it is not recognized by the sulfonylurea and imidazolinone herbicides. Consequently, the enzymatic pathway will continue to work, making the transgenic plants resistant to the herbicide (Haughn et al., 1988; Brasileiro et al., 1992; Aragão et al., 2000).

The sulfonylurea and imidazolinone herbicides inhibit the endogenous AHAS enzyme in the plant tissue. AHAS is the first common enzyme in the metabolic pathway leading to the branched-chain amino acids (leucine, isoleucine and valine). Consequently, the deficiency of these amino acids, accumulation of the toxic substrate ( $\alpha$-ketobutyrate) and an eventual disturbance of the protein synthesis will lead to plant cell death (Chaleff and Mauvais, 1984; Ray, 1984).

Mutated genes that code for an altered form of the AHAS enzyme were also isolated from (a) another plants, such as tobacco and sugar beet; (b) bacteria, such as $E$. coli and S. typhimurium and (c) yeast (Saccharomyces cerevisiae) (Wilmink and Dons, 1993).

The hppd gene: The isoxaflutole (5-cyclopropyl isoxazol4-yl-2-mesyl-4-trifluoromethylphenyl ketone) foliar bleaching herbicide was recently reported as a successful selective agent for soybean transformation (Murh et al., 2000). Isoxaflutole, the active ingredient of the herbicide Balance $^{\mathrm{TM}}$, inhibits the action of 4-hydroxyphenyl pyruvate dioxygenase (HPPD; EC 1.13.11.27), which is an enzyme involved in tyrosine degradation and plastoquinone biosynthesis (Pallett et al., 1998). A mutated hppd gene isolated from Pseudomonas fluorescens codes for an altered form of the enzyme and expresses tolerance to isoxaflutole. The greatest advantage of this selection system is that the transformed tissues become green among the white nontransformed tissues, allowing a simultaneous visual and chemical selection. Transgenic plants resistant to isoxaflutole were also obtained for $A$. thaliana and tobacco.

The hemL gene: A recent paper by Gough et al. (2001) describes the development of a new negative selection system. The mutant glutamate-1-semialdehyde amino-transferase enzyme encoded by the hemL gene isolated from the cyanobacterium Synechococcus PCC6301 strain that gives resistance to gabaculine was expressed in tobacco. Selection was shown to produce explants with green and white phenotypes. The mutated hemL marker gene provides a novel enzyme-based method for the selection of transgenic plants without the need for antibiotic-resistance markers.

The npt II (or neo) gene: The npt II (or neo) gene was isolated from the E. coli transposon Tn5 and codes for the neomycin phosphostransferase II enzyme (NPT II; EC 2.7.1.95), also known as aminoglycoside 3'phosphotransferase II (APH[3]II) (Bevan et al., 1983; Fraley et al., 1983; Herrera-Estrella et al., 1983).

NPT II transfers the $\gamma$-phosphate group of ATP to the 3'-hydroxyl group of the amino-hexose portion of aminoglycoside antibiotics that are consequently detoxificated. Due to this ATP-dependent phosphorylation, binding of the antibiotic to the bacterial ribosome is prevented thus allowing protein synthesis. Aminoglycoside antibiotics that contain the 3 '-hydroxyl group, such as the kanamycins $\mathrm{A}, \mathrm{B}$, and $\mathrm{C}$, neomycin, paramomycin and geneticin (G-418), are substrates for NPT II (Norelli and Aldwinckle, 1993). Endogenous NPT II activity is very rare in plant tissues.

The active aminoglycoside antibiotic inhibits protein synthesis in prokaryote cells by binding to the $30 \mathrm{~S}$ subunit of the ribosome and blocking the formation of initiation complexes and reducing the fidelity of translation. In plant cells, these antibiotics exert their effect on mitochondria and chloroplasts, acting similarly by impairing protein synthesis. These organelles have ribosome that are similar to those found in bacteria and are also susceptible to aminoglycoside antibiotics. Therefore, in the presence of antibiotics, the plant tissue will show chlorosis caused 
by the lack of chlorophyll synthesis and growth inhibition (Benveniste and Davies, 1973; Brasileiro, 1998).

Up to date, $n p t$ II is the selective marker gene most used in plant transformation and kanamycin is the antibiotic most frequently used for the selection of $n p t$ IItransgenic plants.

The hpt (or aph IV) gene: The hpt gene codes for the enzyme hygromycin phosphotransferase (HPT; EC 2.7.1.119), also known as aminoglycoside 4'-phosphotransferase (APH[4]). This gene was isolated from E. coli and gives resistance to the hygromycin B antibiotic (van den Elzen et al., 1985).

HPT catalyses the phosphorylation of the hydroxyl group in the hygromycin antibiotic thus inactivating it. Hygromicin is also an aminoglycoside antibiotic. When active, hygromycin occupies the ribosomal binding site of the elongation factor 2 (EF-2) in prokaryote cells. Consequently, the elongation of the polypeptide chain is inhibited and protein synthesis interrupted, causing the same symptoms described for the other aminoglycoside antibiotics (Benveniste and Davies, 1973).

The hpt gene has been extensively utilized, especially when the use the neo gene is not possible. This is the case of several monocotyledonous species that show high levels of natural resistance to kanamycin (Wilmink and Dons, 1993; Vasil, 1994). Hygromycin B is usually more toxic than kanamycin and kills sensitive cells more quickly.

\section{Chloroplast transformation}

In this system, chloroplasts (or plastids) are transformed with genes for herbicide resistance as in the selection marker process because most target proteins for herbicides are compartmentalized within this organelle. Chloroplast transformation can be accomplished by both the biolistic and polyethylene glycol-mediated strategies (Daniell et al., 1998; Hibberd et al., 1998; Kofer et al., 1998; Sidorov et al., 1999). Vectors that specifically address the integration of the herbicide-resistant marker gene in the chloroplasmatic genome such as the "tobacco vector " or the "universal chloroplast vector" should be preferentially used (Daniell et al., 2001). These vectors possess flanking sequences from highly conserved chloroplast genes to allow integration by homologous recombination. The advantages that chloroplast expression systems may give over routinely nuclear expression are (Bogorad, 2000):
- The retention of the transgene flow (especially marker genes) in microspores is reduced. The chloroplast genome expresses maternal inheritance in most crop plants;

- The expression level of the transgene is extremely high compared with the expression of the same gene integrated in the nuclear genome, due to the large copy number of chloroplast genomes $(5,000$ to 10,000$)$ per cell;

- The insertion in the genome is driven (site-specific), which avoids position effects and facilitates comparative studies;

- The quasi absence of gene silence in the inserted transgenes (Daniell et al., 1998).

In addition, other sub-cellular organelles such as mitochondria might also provide more favorable environments than the nuclear-cytoplasmic compartment for certain biochemical reactions or for high, predictable, uniform and stable transgene expression, not subject to gene silencing (Bogorad, 2000).

Antibiotic-resistant marker genes could be also used in this system, facilitating the extension of plastid transformation to non-green plastids such as in embryogenic cells of cereal crops (Kavanagh et al., 1999; Khan and Maliga, 1999).

\section{Strategies to recover marker-free transgenic plants}

Antibiotic resistance genes (ARGs) have been introduced into transgenic plant genomes. The ARGs are used under control of prokaryotic promoters to select bacteria in vector production for direct plant transformation. In some cases, these prokaryotic ARGs are introduced in the vector along with the gene of interest. In addition, ARGs under the control of eukaryotic promoters are widely used as selection marker genes. Due to biosafety concerns, there have been complex evaluations to study the potential impacts of ARGs present in transgenic plants on human health and the environment. Although there is no evidence of deleterious effects in the use of transgenic plants carrying ARGs, its removal is already stated as "good laboratory practice" by several regulatory committees (U. S. Food And Drug Administration, 1998). Thus it is recommended that those who are developing genetically modified foods for the market should be encouraged to phase out ARGs use (Puchta, 2000; Ow, 2001). This recommendation could also be applied to the other selection marker genes, since they are not necessary once the transgenic plant is obtained. 
Consequently, several strategies to remove the selection marker genes have been developed.

Co-transformation: In this system, the transformation is achieved using two separate plasmid vectors: one containing the gene of interest and other the selective marker gene. In this way, the selective marker gene can be further eliminated by progeny segregation. Thus, the co-transformation system allows the use of a selective agent during plant regeneration and subsequent recovery of marker-free progeny, which contains only the gene of interest. There are at least two basic requirements to make this system functional: (1) the efficiency of co-transformation should be sufficiently high, and (2) the vectors should be integrated in different loci sufficiently "unlinked" to allow effective recovery of recombination events and/or gene segregation.

De Block and Debrouwer (1991) reported that the co-transformation efficiency in oilseed rape with two Agrobacterium strains ranged from 60 to $80 \%$. However, $78 \%$ of these events were in the same locus (linked sites). Other reports stated that, under certain conditions (depending on the transformation vector, transformation methodology, strains of Agrobacterium, plant species etc.), different vectors integrate into unlinked sites at high frequency (Goldsbrough et al., 1993; Yoder and Goldsbrough, 1994; Daley et al., 1998; Tang et al., 1999; Lu et al., 2001; Matthews et al., 2001). Using the biolistic process, the cotransformation of dry bean was $50 \%$ for unlinked genes (Aragão et al., 1996).

MAT (multi-auto-transformation) system: The ipt gene that codes for the enzyme isopentenyl phosphotransferase (EC 2.5.1.27) was isolated from the Ti plasmid of $A$. tumefaciens. The MAT system is primarily based on the visual selection of transgenic plants containing the ipt gene (Ebinuma et al., 1997; Endo et al., 2001; Ebinuma and Komamine, 2001). In the presence of this gene, the transformed plant loses the apical dominance and ability to root. The acquired abnormal phenotype was called extreme shooty phenotype (ESP) and is easy to detect visually. In a second step, the unsuitable ipt gene is removed from the transgenic plant through the transposition of the $A c$ transposable element from maize, which is transferred along with the selection marker gene. In this way, marker-free transgenic plants could be generated with the normal pheno- type restored and containing only the gene of interest. In the MAT vectors, the ipt gene under control of the CaMV $35 \mathrm{~S}$ promoter is inserted into the transposable $A c$ element.

The IPT enzyme catalyzes the condensation of isopentenyl pyrophosphate with AMP to produce isopentenyl AMP, which is a precursor of several cytokinins. Cytokinins stimulate organogenesis in several in vitro cultivated plants and are widely used to regenerate plants after the transformation event.

In the transposition process, only a few excised transposable $A c$ elements (containing the marker gene) disappear from transgenic cells because the $A c$ elements do not reinsert or because they reinsert into a sister chromatid that is further lost by somatic segregation. Therefore, the frequency of the $A c$ element elimination to recover markerfree transgenic plants is low, ranging from 0.1 to $0.5 \%$.

The site-specific $R / R S$ recombination system from Zygosaccharomyces rouxii can also be used to eliminate the marker gene (Sugita et al., 1999; 2000). In this system, the removal of the ipt gene followed by the recovery of marker-free transgenic plants is reported to improve by $70 \%$ over the transposable element $A c$ system.

When the expression of the ipt gene is controlled by a dexamethasone-inducible system, the co-introduction of multiple genes, in addition to ipt, is more efficient and the recovery of marker-free transgenic plants is high (Kunkel et al., 1999).

The MAT system is particularly valuable for plants with long generation cycles such as fruit and forest trees, providing a promising way to shorten breeding time.

Intragenomic relocation of transgenes via transposable elements: In this system, as well as in the MAT system, the selection marker gene should be flanked by the inverted and repeated sequences of the $D s$ element of the $A c / D s$ maize transposable system. Once the transgenic plant has been obtained, the $D s$ element and the marker gene will be transferred to a new locus of the plant genome or eliminated when in the presence of the transposase. The gene of interest will be left in the first insertion locus (Goldsbrough et al., 1993). Transposase can be introduced in this plant as an additional element in the transformation vector by a second transformation or by sexual crossing. The advantage of this system is that the selection marker gene will be lost in some somatic tissues due to failure of the $D s$ element 
reintegration. This makes the strategy suitable for removal of marker genes in vegetatively propagated plants (Yoder and Goldsbrough, 1994; Pavingerova et al., 2001). In a similar way, systems to remove selection marker gene by intrachromosomal recombination between the bacteriophage 1 attachment (attP) regions (Zubko et al., 2000) and by RescueMu transposon have been recently proposed (Raizada et al., 2001).

Site-specific recombination system: This is a two-component system that requires an enzyme that acts in trans to catalyze the recombination between two short specific DNA sequences, which flank the selective marker gene to be eliminated. This system has already been demonstrated to be efficient for yeast. However, in plants, the site-specific recombination rate is very low and the current knowledge of homologous recombination is still limited (Mengiste and Paszkowski, 1999; Vergunst and Hooykaas, 1999). The most common system used to mediate site-specific recombination in plants is the bacteriophage P1 Cre/lox (Yoder and Goldsbrough, 1994; Vergunst and Hooykaas, 1998; Vergunst et al., 1998; Gleave et al., 1999; Corneille et al., 2001). In this recombination system, the plant should be previously transformed with a selection marker gene cloned between two sequences of the lox gene, each with $34 \mathrm{bp}$ repeats in direct orientation. In a second stage, the Cre gene should be introduced in this plant by a second transformation, either by sexual crossing or by transient expression. Once the Cre gene is expressed, the Cre enzyme catalyses the recombination between the lox repeat sequences, thus eliminating the marker gene in the secondary transformants. This recombination strategy can also be used to target the insertion of new genes in an already transformed plant containing the lox sites, or another known sequence, inserted at a "suitable" chromosomal position (Gallego et al., 1999). Site-specific recombination can also be used to compare transgenic plant lines without the effect of the integration site position.

Acknowledgments: We would like to thank Dr. Manoel Teixeira Souza Jr. (Embrapa Recursos Genéticos e Biotecnologia, Brasília - DF) for critical reading of the manuscript. The grants provided to the authors by the Brazilian Council for Research (CNPq-Brazil) are gratefully acknowledged.

\section{REFERENCES}

Aragão FJL, Barros LMG, Brasileiro ACM, Ribeiro SG, Smith FD, Sanford JC, Faria JC, Rech EL (1996) Inheritance of foreign genes in transgenic bean (Phaseolus vulgaris L.) co-transformed via particle bombardment. Theor. Appl. Genet. 93:142-150.

Aragão FJL, Sarokin L, Vianna GR, Rech EL (2000) Selection of transgenic meristematic cells utilizing an herbicidal molecule results in the recovery of fertile transgenic soybean [Glycine $\max (\mathrm{L}$.) Merril] plants at high frequency. Theor. Appl. Genet. 101:1-6.

Benveniste R, Davies J (1973) Mechanisms of antibiotic resistance in bacteria. Annu. Rev. Biochem. 42:471-506.

Bevan MW, Flavell RB, Chilton MD (1983) A chimaeric antibiotic resistance gene as a selectable marker for plant cell transformation. Nature 304:184-187.

Bogorad L (2000) Engineering chloroplasts: an alternative site for foreign genes, proteins, reactions and products. Trends Biotech. 16:257-263.

Bowen BA (1993) Markers for plant gene transfer. In: Kung S, Wu R (eds), Transgenic Plants, pp.89-123. Academic Press Inc., San Diego, USA.

Brasileiro ACM (1998) Neomicina Fosfotransferase II (NPT II). In: Brasileiro ACM, Carneiro VTC (eds), Manual de Transformação Genética de Plantas, pp.143-154. Embrapa-SPI/Embrapa-Cenargen, Brasília, Brazil.

Brasileiro ACM, Dusi DMA (1999) Transformação genética de plantas. In: Torres AC, Caldas LS, Buso JA (eds), Cultura de Tecidos e Transformação Genética de Plantas, pp.679-735. Embrapa-SPI/Embrapa-CNPH, Brasília, Brazil.

Brasileiro ACM, Tourneur C, Leplé JC, Combes V, Jouanin L (1992) Expression of the mutant Arabidopsis thaliana acetolactate synthase gene confers chlorsulfuron resistance to transgenic poplar plants. Transg. Res. 1:133-141.

Chaleff RS, Mauvais CJ (1984) Herbicide-resistant mutants from tobacco cell cultures. Science 223:1148-1151.

Comai L, Facciotti D, Hiatt WR, Thompson G, Rose RE, Stalker DM (1985) Expression in plants of a mutant aroA gene from Salmonella typhimurium confers tolerance to glyphosate. Nature 317:741-744.

Comai L, Sen LC, Stalker DM (1983) An altered aroA gene product confers resistance to the herbicide glyphosate. Science 221:370-371. 
Corneille S, Lutz K, Svab Z, Maliga (2001) Efficient elimination of selectable marker genes from the plastid genome by the CRE-lox site-specific recombination system. Plant J. 27:171-178.

Daley M, Knauf VC, Summerfelt KR, Turner JC (1998) Co-transformation with one Agrobacterium tumefaciens strain containing two binary plasmids as a method for producing marker-free transgenic plants. Plant Cell Rep. 17:489-496.

Daniell H, Datta R, Varma S, Gray S, Lee SB (1998) Containment of herbicide resistance through genetic engineering of the chloroplast genome. Nature Biotech. 16:345-348.

Daniell H, Wiebe PO, Millan AF (2001) Antibiotic-free chloroplast genetic engineering - an environmentally friendly approach. Trends Plant Sci. 6:237-239.

De Block M, Botterman J, Vanderwiele M, Dockx J, Thoen C, Gossele V, Rao Movva N, Thompson C, Van Montagu M, Leemans J (1987) Engineering herbicide resistance in plants by expression of a detoxifying enzyme. EMBO J. 6:2513-2518.

De Block M, Debrouwer D (1991) Two T-DNAs co-transformed into Brassica napus by a double Agrobacterium infection are mainly integrated at the same locus. Theor. Appl. Genet. 82:257-263.

Ebinuma H, Sugita K, Matsunaga E, Yamakado M (1997) Selection of marker-free transgenic plants using the isopentenyl transferase gene. Proc. Natl. Acad. Sci. USA 94:2117-2121.

Ebinuma H, Komamine A (2001) MAT (Multi-Auto-Transformation) vector system. The oncogenes of Agrobacterium as positive markers for regeneration and selection of marker-free transgenic plants. In Vitro Cel. Dev. Biol. Plant 37:103-113.

Endo S, Kasahara T, Sugita K, Matsunaga E, Ebinuma H (2001) The isopentenyl transferase gene is effective as a selectable marker gene for plant transformation in tobacco (Nicotiana tabacum cv. Petite Havana SRI). Plant Cell Rep. 20:60-66.

Fraley RT, Rogers SG, Horsch RB, Sanders PR, Flick JS, Adams SP, Bittner ML, Brand LA, Fink CL, Fry JS, Galluppi GR, Goldberg SB, Hoffmann NL, Woo SC (1983) Expression of bacterial genes in plant cells. Proc. Natl. Acad. Sci. USA 80:4803-4807.
Gallego ME, Sirand-Pugnet P, White CI (1999) Positivenegative selection and T-DNA stability in Arabidopsis transformation. Plant Mol. Biol. 39:83-93.

Gleave AP, Mitra DS, Mudge SR, Morris BAM (1999) Selectable marker-free transgenic plants without sexual crossing: transient expression of cre recombinase and use of a conditional lethal dominant gene. Plant Mol. Biol. 40:223-235.

Goldsbrough AP, Lastrella CN, Yoder JI (1993) Transposition mediated repositioning and subsequent elimination of marker genes from transgenic tomato. Bio/Tech. 11:1286-1292.

Gough KC, Hawes WS, Kilpatrick J, Whitelam GC (2001) Cyanobacterial GR6 glutamate-1-semialdehyde aminotransferase: a novel enzyme-based selectable marker for plant transformation. Plant Cell Rep. 20:296-300.

Haldrup A, Petersen SG, Okkels FT (1998a) The xylose isomerase gene from Thermoanaerobacterium thermosulfurogenes allows effective selection of transgenic plant cells using D-xylose as the selection agent. Plant Mol. Biol. 37:287-296.

Haldrup A, Petersen SG, Okkels FT (1998b) Positive selection: a plant selection principle based on xylose isomerase, an enzyme used in the food industry. Plant Cell Rep. 18:76-81.

Haughn GW, Smith J, Mazur B, Somerville C. (1988) Transformation with a mutant Arabidopsis acetolactate syntase gene renders tobacco resistant to sulfonylurea herbicides. Mol. Gen. Genet. 211:266-271.

Herrera-Estrella L, De Block M, Messens E, Hernalsteens JP, Van Montagu M, Schell J (1983) Chimeric genes as dominant selectable markers in plant cells. EMBO J. 2:987-995.

Hibberd JM, Linley PJ, Khan MS, Gray JC (1998) Transient expression of green fluorescent protein in various plastid types following microprojectile bombardment. Plant J. 16:627-632.

Joersbo M, Donaldson I, Kreiberg J, Petersen SG, Brunstedt J, Okkels FT (1998) Analysis of mannose selection used for transformation of sugar beet. Mol. Breed. 4:111-117.

Joersbo M, Mikkelsen JD, Brunstedt J (2000) Relationship between promoter strength and transformation frequencies using mannose selection for the production of transgenic sugar beet. Mol. Breed. 6:207-213. 
Joersbo M, Okkels FT (1996) A novel principle for selection of transgenic plant cells: positive selection. Plant Cell Rep. 16:219-221.

Joersbo M, Petersen SG, Okkels FT (1999) Parameters interacting with mannose selection employed for the production of transgenic sugar beet. Physiol. Plant. 105:109-115.

Kavanagh TA, Thanh ND, Lao NT, Mcgrath N, Peter SO, Horvath EM, Dix PJ, Medgyesy P (1999) Homeologous plastid DNA transformation in tobacco is mediated by multiple recombination events. Genetics 152:1111-1122.

Khan MS, Maliga P (1999) Fluorescent antibiotic resistance marker for tracking plastid transformation in higher plants. Nature Biotech. 17:910-915.

Kofer W, Eibl C, Steinmuller K, Koop HU (1998) PEGmediated plastid transformation in higher plants. In Vitro Cel. Dev. Biol. Plant 34:303-309.

Kunkel T, Niu QW, Chan YS, Chua NH (1999) Inducible isopentenyl transferase as a high-efficiency marker for plant transformation. Nature Biotech. 17:916-919.

Kunze I, Ebneth M, Heim U, Geiger M, Sonnewald U, Herbers K (2001) 2-Deoxyglucose resistance: a novel selection marker for plant transformation. Mol. Breed. 7:221-227.

Lindsey K (1992) Genetic manipulation of crop plants. J. Biotech. 26:1-28, 1992.

Lu HJ, Zhou XR, Gong ZX, Upadhyaya NM, Lu HJ, Zhou XR, Gong ZX (2001) Generation of selectable markerfree transgenic rice using double right-border (DRB) binary vectors. Aust. J. Plant Physiol. 28:241-248.

Matthews PR, Wang MB, Waterhouse PM, Thornton S, Fieg SJ, Gubler F, Jacobsen JV, Wang MB (2001) Marker gene elimination from transgenic barley, using co-transformation with adjacent 'twin T-DNAs' on a standard Agrobacterium transformation vector. Mol. Breed. 7:195-202.

Mazur BJ, Falco SC (1989) The development of herbicide resistant crops. Annu. Rev. Plant Physiol. 40:441-470.

Mengiste T, Paszkowski J (1999) Prospects for the precise engineering of plant genomes by homologous recombination. Biol. Chem. 380:749-758.

Mourad G, Williams D, King J (1995) A double mutant allele, crs1-4, of Arabidopsis thaliana encodes an acetolactase synthase with altered kinetics. Planta 196:64-68.
Murakami T, Anzai H, Imai S, Satoh A, Nagaoka K, Thompson CJ (1986) The bialaphos biosynthetic genes of Streptomyces hygroscopicus: molecular cloning and characterization of the gene cluster. Mol. Gen. Genet. 205:42-50.

Murh C, Garçon F, Betka S, Le-Roux S, Lestrade B, Portelatine L, Sailland A, Pélissier B (2000) Use of isoxaflutole as selectable marker for soybean transformation. In: Proceedings of the 8th Biennial Conference of the Cellular and Molecular Biology of the Soybean. Lexington, USA, p. B20.

Negrotto D, Jolley M, Beer S, Wenck AR, Hansen G (2000) The use of phosphomannose-isomerase as a selectable marker to recover transgenic maize plants (Zea mays L.) via Agrobacterium transformation. Plant Cell Rep. 19:798-803.

Norelli JL, Aldwinckle HS (1993) The role of aminoglycoside antibiotics in the regeneration and selection of neomycin phosphotransferase-transgenic apple tissue. J. Am. Soc. Hortic. Sci. 118:311-316.

Okkels FT, Ward J, Joersbo M (1997) Synthesis of cytokinin glucuronides for the selection of transgenic plant cells. Phytochemistry 46:801-804.

Oxtoby E, Hughes M A (1990) Engineering herbicide tolerance into crops. Trends Biotech. 8:61-65.

Ow DW (2001) The right chemistry for marker gene removal? Nature Biotech. 19:115-116.

Pallett KE, Little JP, Sheekey M, Veerasekaran P (1998) The mode of action of isoxaflutole I. Physiological effects, metabolism, and selectivity. Pestic. Biochem. Physiol. 62:113-124.

Pavingerova D, Briza J, Niedermeierova H (2001) Timing of transposition of $A c$ mobile element in potato. Biol. Plant. 44:347-353.

Puchta H (2000) Removing selectable marker genes: taking the shortcut. Trends Plant Sci. 5:273-274.

Raizada MN, Nan GuoLing, Walbot V, Nan GL (2001) Somatic and germinal mobility of the RescueMu transposon in transgenic maize. Plant Cell 13:15871608 .

Ray TB (1984) Site of action of chlorsulfuron. Plant Physiol. 75:827-831.

Sawahel WA (1994) Transgenic plants: performance, release and containment. World J. Microbiol. Biotech. 10:139-144. 
Sidorov VA, Kasten D, Pang SZ, Hajdukiewicz PTJ, Staub JM, Nehra NS (1999) Stable chloroplast transformation in potato: use of green fluorescent protein as a plastid marker. Plant J. 19:209-216.

Stein JC, Hansen G (1999) Mannose induces an endonuclease responsible for DNA laddering in plant cell. Plant Physiol. 121:1-9.

Sugita K, Kasahara T, Matsunaga E, Ebinuma H (2000) A transformation vector for the production of marker-free transgenic plants containing a single copy transgene at high frequency. Plant J. 22:461-469.

Sugita K, Matsunaga E, Ebinuma H (1999) Effective selection system for generating marker-free transgenic plants independent of sexual crossing. Plant Cell Rep. 18:941-947.

Tang KX, Tinjuangjun P, Xu Y, Sun XF, Gatehouse JA, Ronald PC, Qi HX, Lu XG, Christou P, Kohli A (1999) Particle-bombardment-mediated co-transformation of elite Chinese rice cultivars with genes conferring resistance to bacterial blight and sap-sucking insect pests. Planta 208:552-563.

U. S. Food and Drug Administration. (1998) Guidance goes industry: use of antibiotic resistance marker genes in transgenic plants. http://vm.cfsan.fda.gov/ dms/opaarm. September, 4 .

Vain P, De Buyser J, Bui Trang V, Haicour R, Henry Y (1995) Foreign gene delivery into monocotyledonous species. Biotech. Adv. 13:653-671.

Van Den Elzen PJM, Townsend J, Lee KY, Bedbrook JR (1985) A chimaeric hygromycin resistance gene as a selectable marker in plant cells. Plant Mol. Biol. 5:299-302.

Vasil IK (1994) Molecular improvement of cereals. Plant Mol. Biol. 25:925-937.
Vergunst AC, Hooykaas PJJ (1998) Cre/lox-mediated sitespecific integration of Agrobacterium T-DNA in Arabidopsis thaliana by transient expression of cre. Plant Mol. Biol. 38:393-406.

Vergunst AC, Hooykaas PJJ (1999) Recombination in the plant genome and its application in biotechnology. Crit. Rev. Plant Sci. 18:1-31.

Vergunst AC, Jansen LET, Hooykaas PJJ (1998) Site-specific integration of Agrobacterium T-DNA in Arabidopsis thaliana mediated by Cre recombinase. Nucl. Acid Res. 26:2729-2734.

Vincentz M, Caboche M (1991) Constitutive expression of nitrate reductase allows normal growth and development of Nicotiana plumbaginifolia plants. EMBO J. 10:1027-1035.

Wang AS, Evans RA, Altendorf PR, Hanten JA, Doyle MC, Rosichan JL (2000) A mannose selection system for production of fertile transgenic maize plants from protoplast. Plant Cell Rep. 19:654-660.

Wilmink A, Dons JJM (1993) Selective agents and marker genes for use in transformation of monocotyledonous plants. Plant Mol. Biol. Rep. 11:165-185.

Wright M, Dawson J, Dunder E; Suttie J, Reed J, Kramer C, Chang Y, Novitzky R, Wang H, Artim-Moore, L (2001) Efficient biolistic transformation of maize (Zea mays L.) and wheat (Triticum aestivum L.) using the phosphomannose isomerase gene, pmi, as the selectable marker. Plant Cell Rep. 20:429-436.

Yoder JI, Goldsbrough AP (1994) Transformation systems for generating marker-free transgenic plants. Bio/Tech. 12:263-267.

Zubko E, Scutt C, Meyer P (2000) Intrachromosomal recombination between attP regions as a tool to remove selectable marker genes from tobacco transgenes. Nature Biotech. 18:442-445. 